\title{
Experimental Tuberculous Infection in Mice
}

\author{
By \\ Kyuzo Omachi \\ (大町 久藏)
}

(From the Department of Bacteriology, Faculty of Medicine, Tohoku University; Sendai; Director: Prof. M. Kuroya)

(Received for publication, August 18, 1952)

Since many successes have followed in the discovery of antibiotics curative in acute bacterial infections, our special attention has been focused on those diseases, against which such success has not yet been so satisfactory, especially on human tuberculosis.

As reported already in our systematic studies on actinomyces anti biotics, roseomycin, anti-phlei factor (No. 364), flaveolin, glyseoflavin and vinacetin have been isolated and they have shown some activities against tubercle bacilli in vitro.

But, a further study required the establishment of standardized animal experiment, ${ }^{13) 3(4)}$ i.e. the selection of a satisfactory experimental animal and a simple quantitative pursuance method of the bacilli in the tuberculous tissues.

Since the discovery of streptomycin, animal experiments against

Mycobacterium tuberculosis were discussed by many authors. ${ }^{56677}$ Some of them used guinea-pigs, and others used mice. Although in the past the rabbit and mouse have also been used, most of the authors chose guinea-pigs for chemotherapeutic experiments.

In my opinion, however, it is a so interesting fact, that the intravenous inoculation of the bacilli into mice causes a specially severe lesion of the lung as shown in human beings.

In this respect Arimura ${ }^{11}$ et al. discussed the specificity of mice tuberculosis comparing with that of other animals, and Youmans ${ }^{2)}$ emphasized the characteristic lung lesion in the curative experiment by streptomycin.

Recently McKee et al..$^{5}$ described many advantages of mice tuberculosis using the pure bleed strains. The use of mice in chemotherapeutic experiment against tuberculosis will present the following advantages:

1) The estimation of the effectiveness will be decided in a rather short time.

2) A relatively small quantity of the antibiotic will be suffcient to treat the infected animals, and as the results, we can treat many animals with small quantities of remedies. From the economical point too, it 
enabled us to use the large number of animals in such an experiment.

3) As described above, a special lesion in lungs is a favourable fact, for the final purpose is chiefly concerned with the human lung tuberculosis*

4) The recent advances in the quantitative estimation of tubercle bacilli in tissues will afford the statistical treatment of the results.

5) Even the cross breed mice have shown identical changes, being compared with the pure breed ones, as shown in my preliminary experiments. So, when summarized results of the experiment will be judged from these points of view, not only from pathological changes, the use of mice has no shortage being compared with that of guinea-pigs.

From the above point of view, some experiments of mice tuberculosis were conducted and will be reported here.

\section{EXPERIMENTAL}

Exp. I. The distribution of living tubercle bacilli in several viscera after intraperitoneal injection of avian tubercle bacilli, " Flemingo." strain.

Twelve white mice (mixed breed), weighing 15 to $18 \mathrm{~g}$., were divided into 4 groups, composed of 3 animals each, and infected intraperitoneally with $0.1,0.25,0.5$ and $1.0 \mathrm{mg}$. (moist weight) of Flemingo strain, respectively. At 10th, 20th and 30th day after inoculation one animal of each group was sacrificed and tested upon the amount of bacilli from

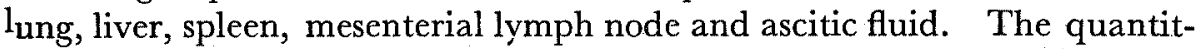
ative cultivation method was conducted according to Ogawa ${ }^{10111}$ as follows. Each of the organs was removed, weighed, and the weighed amounts of them were completely ground in a porcelain mortar, adding 10 volumes of dil. sulphuric acid (4 per cent). After centrifugation 3000 r.p.m. for $10 \mathrm{~min}$., the residue was suspended in the same volume of physiological saline, diluted further in 10 fold serially and $0.2 \mathrm{cc}$. of these suspensions were inoculated into each of 3 tubes of Oka-Katakura's egg media. After cultivation at $37^{\circ} \mathrm{C}$ for 4 weeks, the number of colonies were counted.

As shown in Table I,

1) 2 mice died in the course of the experiment, and the reason of death was confirmed to be not of tuberculosis by necropsic findings.

2) Macroscopically, the extensive involvement of the lung was never seen in any animals. Only in severe infected groups $(0.5$ and $1.0 \mathrm{mg}$. each), slight pathological changes due to tuberculosis were found in the spleen, liver and partially in lymph node.

3) The tubercle bacilli were already proved after 10 days from the infection, especially in the liver, spleen and lymph nodes, but even after 30 days the number of colonies was not so increased. It is of interest, that there is no dissemination of the bacilli in lung by the intraperitoneal 


\section{TABLE I}

The Distribution of Living Tubercle Bacilli in Various Viscera, after Intraperitoneal Injection of Avian

Tubercle Bacilli (Flemingo Strain)

\begin{tabular}{|c|c|c|c|c|c|c|c|c|c|c|c|c|}
\hline \multicolumn{3}{|c|}{ Organs } & \multicolumn{2}{|c|}{ Lung } & \multicolumn{2}{|c|}{ Liver } & \multicolumn{2}{|c|}{ Spleen } & \multicolumn{2}{|c|}{ Lymph nodes } & \multicolumn{2}{|c|}{ Ascitic fluid } \\
\hline 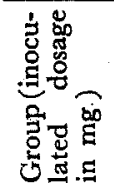 & 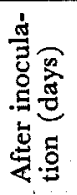 & 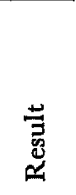 & 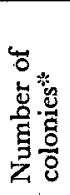 & 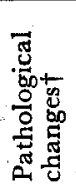 & 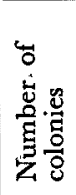 & 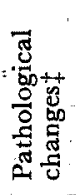 & 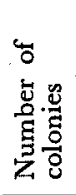 & 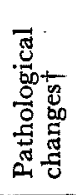 & 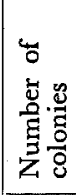 & 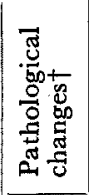 & 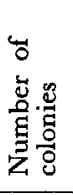 & 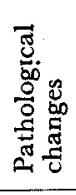 \\
\hline \multirow{3}{*}{$\underset{(0.1)}{\mathbf{I}}$} & 10 & killed & - & - & Ht & & H & - & H & - & + & - \\
\hline & 14 & died & - & - & H & & H & - & H & - & + & - \\
\hline & 30 & killed & - & - & H & & $H$ & + & H & - & + & - \\
\hline \multirow{3}{*}{$\begin{array}{c}\text { II } \\
(0.2)\end{array}$} & 8 & died & H. & - & H & & H & - & \# & - & - & - \\
\hline & 10 & killed & $H$ & - & $H$ & & H & - & H & - & + & - \\
\hline & 30 & killed & + & - & H & & \# & - & H & - & + & - \\
\hline \multirow{3}{*}{$\begin{array}{c}\text { III } \\
(0.5)\end{array}$} & 10 & killed & + & - & H & & $H$ & + & H & - & H & - \\
\hline & 20 & $"$ & $H$ & - & \# & & H & H & $H$ & - & + & - \\
\hline & 30 & $"$ & + & - & 世 & & $H$ & $H$ & H & - & H & - \\
\hline \multirow{3}{*}{$\begin{array}{c}\text { IV } \\
(1.0)\end{array}$} & 10 & killed & + & - & H & & + & H. & $H$ & - & + & - \\
\hline & 20 & $"$ & H & - & \# & & \# & H & H & - & + & - \\
\hline & 30 & $"$ & \# & - & 井 & & $H^{-}$ & H & \# & H & + & $=$ \\
\hline
\end{tabular}

* Number of colonies was indicated by the symbol,,$-+ H$ and $\#$, according to the degrees of the bacterial growth.

† The graded phathological changes were judged as follows:

$$
\begin{array}{lll}
\text { Lung: } & \text { Spleen (expressed } & \text { Mesenterial lymph } \\
& \text { in weight): } & \text { nodes: }
\end{array}
$$

- No tubercle

+ Dissemination of smallest - Below $100 \mathrm{mg}$. - No tubercle tubercles $(0.5-1.0 \mathrm{~mm}$.

in diameter) $\quad+$ Over $100 \ldots+$ Small tubercle

\# Dissemination of small \# Over 200 .. \# Middle " tubercles $(1-2 \mathrm{~mm}$. in diameter)

\#- Over 300 , \# Large ",

\# Many tubercles

卌 Over 400 ,

HW - Many large tuberctes were adhered with each other

$\ddagger$ Macroscopic findings of the liver were difficult to be recorded in score, so data were not shown.

infection especially in the case of small inoculum (0.1 mg.).

Exp. II. The distribution of living bacilli in several viscera after 
intravenous infection of human tubercle bacilli $\left(\mathrm{H}_{37} \mathrm{Rv}\right)$.

27 white mice weighing $14-18 \mathrm{~g}$. were divided into 3 groups composed of 9 mice each. Each of 3 groups was inoculated intravenously with $0.01,0.02$ and $0.05 \mathrm{mg}$. (moist weight) of virulent human tubercle bacilli $\left(\mathrm{H}_{37} \mathrm{Rv}\right)$, respectively. At 15 th, 25 th and 35 th day after infection, $2-3$ mice of each group were killed and tested on the number of bacilli from lung, liver, spleen, lymph nodes and ascitic fluid.

The applied method here is as follows. For the first autopsy," after 15 days the weighed amount of each of organs was ground in a porcelain mortar with 10 volumes of sulphuric acid ( 4 per cent) under aseptic condition, and the suspension was centrifugated 3000 r.p.m. for $10 \mathrm{~min}$. The supernatant was discarded, the residue was resuspended in the same volume of physiological saline and diluted in 10 fold serially. $0.5 \mathrm{cc}$. of the suspension were inoculated into each of 3 tubes of Oka-Katakura's egg media. In 2nd and 3rd autopsy, however, the weighed amount of each of organs was ground in 10 volumes of 4 per cent $\mathrm{NaOH}$ solution, diluted in 10 fold serially and $0.2 \mathrm{cc}$. of the suspensions were inoculated

TABLE II

The Distribution of Living Tubercle Bacilli in Various Viscera, after Intravenous Injection of Human Tubercle Bacilli $\left(\mathrm{H}_{3 \mathbf{i}} \mathrm{Rv}\right.$ Strain)

\begin{tabular}{|c|c|c|c|c|c|c|c|c|c|c|c|c|}
\hline \multirow{3}{*}{ 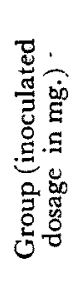 } & \multirow{3}{*}{ 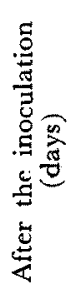 } & \multirow{3}{*}{ 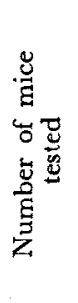 } & \multicolumn{10}{|c|}{ Organs } \\
\hline & & & \multicolumn{2}{|c|}{ Lung } & \multicolumn{2}{|c|}{ Liver } & \multicolumn{2}{|c|}{ Spleen } & \multicolumn{2}{|c|}{ Lymph nodes } & \multicolumn{2}{|c|}{ Ascitic fluid } \\
\hline & & & 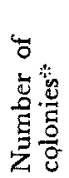 & 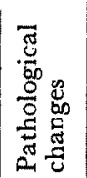 & 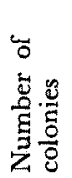 & 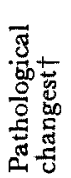 & 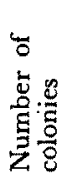 & 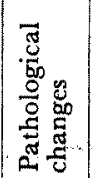 & 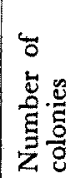 & 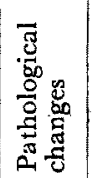 & 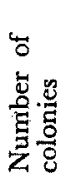 & 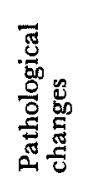 \\
\hline \multirow{3}{*}{$\begin{array}{c}\mathbf{I} \\
(0.01)\end{array}$} & 15 & 3 & 0.3 & --- & 0.3 & & 0.7 & --+ & 0 & --- & 0 & -- \\
\hline & 25 & 3 & 6.4 & -++ & 0.6 & & 6.0 & +++ & 0 & $(---)$ & 0 & --- \\
\hline & 35 & 2 & 21.0 & +4 & 1.1 & & 15.5 & mH & 0.03 & -1 & 0 & $\rightarrow-$ \\
\hline \multirow{3}{*}{$\begin{array}{c}\text { II } \\
(0.02)\end{array}$} & 15 & 2 & 1.0 & -- & 0.3 & & 2.0 & H\# & 0 & -- & 0 & -- \\
\hline & 25 & 3 & 11.8 & $+H+$ & 0.9 & & 9.1 & HHH & 0 & --- & 0 & --- \\
\hline & 35 & 3 & 18.0 & $H+H$ & 1.5 & & 18.0 & $H+H+H$ & 0.1 & -- & 0.03 & -- \\
\hline \multirow{3}{*}{$\begin{array}{c}\text { III } \\
(0.05)\end{array}$} & 15 & 3 & 7.0 & --- & 0,8 & & 7.3 & Htwt + t+ H & 0 & --- & 0 & --- \\
\hline & 25 & 3 & 13.6 & $\mathrm{HHH}$ & 1.5 & & 8.5 & HAH & 0 & -- & 0 & $-\ldots$ \\
\hline & 35 & 3 & 27.5 & HWH & 3.2 & & 19.0 & $H \#$ H & 0.32 & $-\cdots$ & 0.04 & $--\div$ \\
\hline
\end{tabular}

* Number of colonies was expressed per $1 \mathrm{mg}$. of each organ.

† The same as shown in Table I. 
into each of 3 tubes of Ogawa's egg média. After cultivation at $37^{\circ} \mathrm{C}$. for 4 weeks, the number of colonies was counted.

All the results are shown in Table II. days. ${ }^{10 k}$

1) In the course of the experiment only 2 mice died within 35

2) The number of colonies shown in Table II are expressed per $1 \mathrm{mg}$. of the organ tissue.. With lung, liver and spleên materials the colonies were proved early in 15 days, but with lymph nodes and ascitic fluid even 25 days after injection no colonies have been proved, until it was found in a very small number after 35 days.

3) Comparative study of the number of colonies in each group indicated that, when the more inoculum was injected the more colonies were found in every viscera after 15 days.

4) After 15 days, the increasing number of colonies was found in the order of spleen, lung and liver, although no remarkable differences were observed among them. After 25 days the more colonies were found in the order of lung, spleen and liver, namely the bacilli in lung tissue were especially increased in the later period of disease. After 35 days the order is the same as after 25 days. In this experiment it was proved, that the increasing grade of the bacilli in liver seemed to be somewhat slower than in lung and spleen.

5) After 15 days the pathological changes were compared macroscopically. In lung there were no visible evidences of the disease in any group. All of mice were increasing in the weight of spleen already after 15 days except the first group which was injected with $0.01 \mathrm{mg}$. of bacilli. Macropathological findings were also increasing with the course of disease except lymph nodes and ascitic fluid where no evidence of disease was found until 35 days.

Exp. III. The development of bacilli in liver tissue, examined by repeated resection of liver-pieces.

Sixteen white mice weighing 14-18 g. were devided into 4 groups consisting from 4 mice each. All mice were inoculated intravenously with $0.05 \mathrm{mg}$. (moist weight) of virulent human-type tubercle bacilli $\left(\mathrm{H}_{3 i} \mathrm{Rv}\right)$.

As shown in Table III, after one week of infection all animals of the 1st group, after 2 weeks those of the 2nd group, after 3 weeks those of the 3rd group, and after 4 weeks those of the 4th group, were operated up for liver resections. The operation was repeated in such a manner, as after 5 weeks the 2nd operation of those of the 1st group was carried out, and under such a schedule the resections were repeated 3-4 times in every animal of all groups, being continued until 16 weeks after in 


\section{TABLE, III}

The Development of Living Tubercle Bacilli.

Number of. Golonies Cultivated: from .

Liver-pieces

The figures indicate the number of colonies, obtained by the cultivation of diluted liver suspensions; shown in table

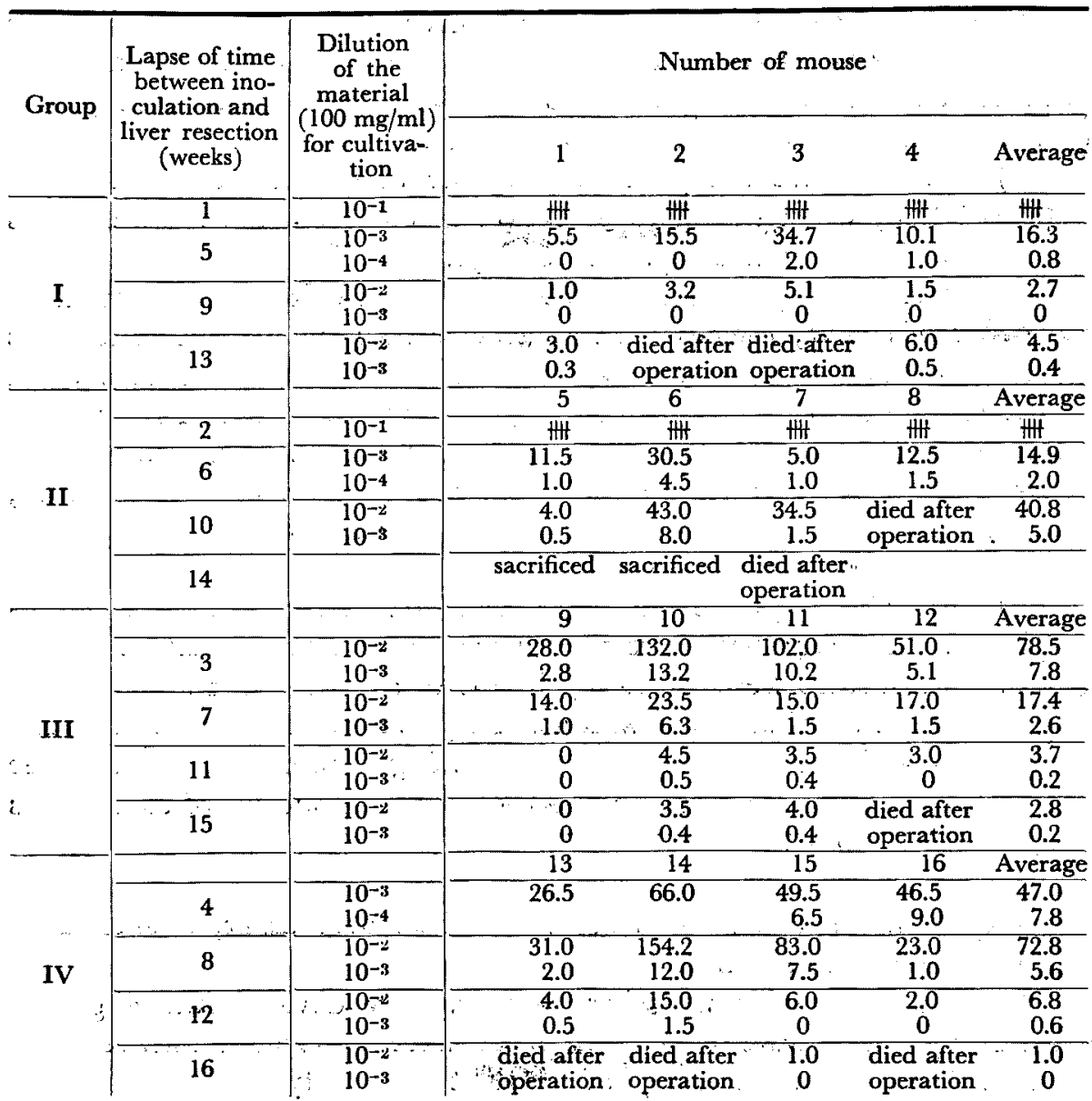

oculation at last.

From all the pieces of liver, resected in the manner mentioned above, the tubercle bacilli were cultivated immediately after resection as described later.

The weight of liver pieces resected was 50 to $100 \mathrm{mg}$. each, and occurring hemorrhage was in no need of treatment, except that after the resection peritoneum and skin were sewn up together and $0.5 \mathrm{cc}$ of physi- 
ological saline was injected subcutaneously. Accidental deaths by this operation were scarcely observed even after repeated operations as shown in Table III. . So it seems to be available for its simplicity and for its quantitative character to pursue the development of bacilli in tissues.

The autopsy of dead animals during the schedule of liver resections was conducted immediately after the death of animals, if any, and that of living animals was carried out at the suitable time, between 1-5 weeks after the last resection, i.e. between 17-21 weeks after inoculation, and the tubercle bacilli from lungs, livers, spleens and both kidneys including the liver pieces resected were cultured according to Ogawa's method. ${ }^{11}$ The weighed amounts of materials were ground in 10 volumes of 1 per cent $\mathrm{NaOH}$ solution, and diluted further with same solution 10 fold serially as $10^{-1}, 10^{-2}, 10^{-3}$, and $10^{-4}$. $0.1 \mathrm{cc}$. of each diluent was inoculated into 2 or 3 tubes of Ogawa's media.

Results obtained were shown in Table III, IV and V.

1) The moltality of animals by this operations was as follows. After the 1st operation no mice died, and after the 2nd operation died only 1 mouse under 16. But, after the 3rd operation 7 mice died among 15.

2) The maximum number of colonies cultivated from the resected

TABLE IV

Number of Colonies Cultivated from Liver-pieces

\begin{tabular}{c|c|c|c|c}
\hline $\begin{array}{c}\text { Lapse of time } \\
\text { between inocu- } \\
\text { lation and } \\
\text { liver resection } \\
\text { (weeks) }\end{array}$ & \multicolumn{3}{|c|}{$\begin{array}{c}\text { Number of colonies cultivated from liver- } \\
\text { pieces at the dilution of }\end{array}$} \\
\cline { 2 - 4 } & $10^{-1}(100 \mathrm{mg} / \mathrm{ml})$ & $10^{-2}$ & $10^{-3}$ & $10^{-4}$ \\
\hline 1 & $1 \mathrm{H}$ & & & \\
2 & $\mathrm{H}$ & & & \\
3 & & 76.5 & 7.8 & \\
4 & & & 47.0 & 7.8 \\
5 & & & 16.3 & 0.8 \\
6 & & & 14.9 & 2.0 \\
7 & & 17.4 & 2.6 & \\
8 & & & 5.6 & \\
9 & & & 2.7 & 0 \\
10 & & 30.5 & 3.3 & \\
11 & & 3.7 & 0.2 & \\
12 & & 6.8 & 0.6 & \\
13 & & 4.5 & 0.4 & \\
14 & & 3.0 & 0 & \\
15 & & 2.8 & 0 & \\
16 & & 1.0 & 0 &
\end{tabular}




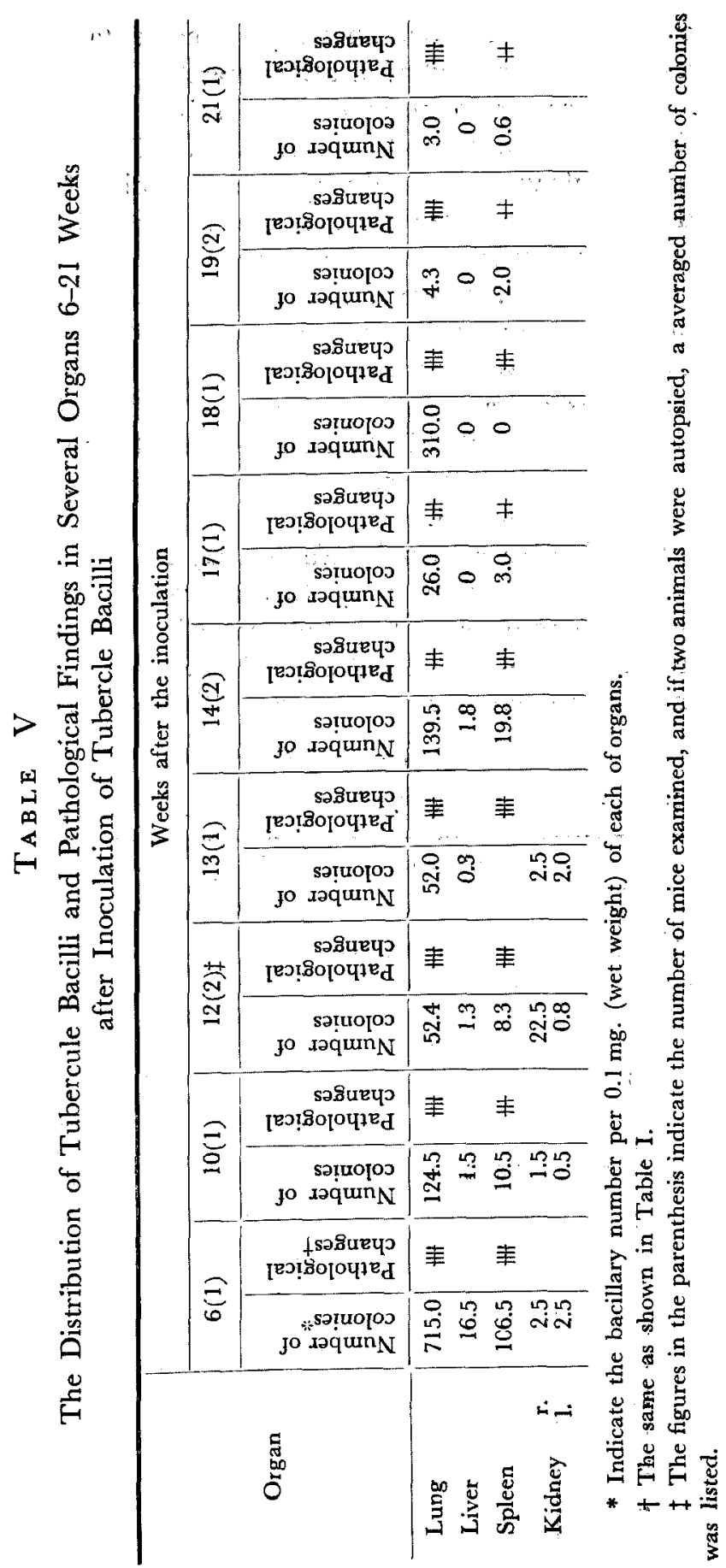


liver-pieces was reached after 4-6. weeks after inoculation, and hereafter decreasing tendency was observed (Table IV). This spontaneous recovery tendency must be fully attended at the judgement of the curative effect of antibiotics.

3) As shown in Table III in details, it seems to be so advantageous that the deviation in the colony numbers in the same group is not so large.

4) The distribution of tubercle bacilli in every organ of the dead or killed animals was presented in Table V. They were autopsied all over $6-21$ weeks after the infection and the maximum of the colony number of all materials was proved in case after 6 weeks, and hereafter a decreasing tendency of colonies was proved in these cases too. In any cases the more colonies were found in the order of lung, spleen, liver and kidneys. In kidneys usually some more colonies were found in the right side than the left.

5) Visible pathological changes were most evident in lungs and sometimes many tubercles $1-2 \mathrm{~mm}$. in diameters, were adhered with each other. In liver 2 or 3 smallest tubercles were found usually. These tissues were preserved for histopathological studies.

\section{SUMMARY}

1. 3 experiments in mice tuberculosis, the one with intraperitoneal injection of avian tubercle bacilli (Flemingo strain), and the other two with intravenous injection of human tubercle bacilli $\left(\mathrm{H}_{3 i} \mathrm{Rv}\right)$ were conducted.

In several stages after infection they were sacrificed and the macropathological findings were observed. The development of the disease, however, were chiefly judged by the cultivation test of the bacilli from lung, liver, spleen, lymph nodes and kidneys.

2. For the quantitative pursuance of the living bacilli, the resections of liver-pieces from the tuberculous mice were carried out repeatedly. The accidental death after this operation was not so often, the availability of this method being ascertained.

3. When Flemingo strain was injected intraperitoneally, the bacilli developed chiefly in livers, spleens and lymph nodes, but only little in lungs. Contrary to this intravenous injection of human tubercle bacilli caused the chief lesions in lungs and also in spleens. The natural healing tendency observed in the latter must be attended at the judgment of chemotherapeutic experiment.

In conclution, I wish to express my sincere appreciation to Prof. M. Kuroya for his continued encouragement. 


\section{References}

1) Feldman, W. H. and Hinshow, H. G., Proc. Mayo Clinic, 1949, 19, 593.

2) Youmans, G. P. and McCarter, J. C., Am. Rev. Tuberc., 1945, 52, 432.

3) Smith, M. J. and McClosky, W. T., Publ. Health Rep. 1945, 60, 1129.

4) Yanagisawa, K., Rinsho (Japanese), 1949, 2, 419.

5) McKee, G. M., Rake, G., Donovick, R. and Jamber, W. P., Am. Rev. Tuberc., 19.19, 60,90 .

6) Donovick, R., McKee, C. M., Jamber, W. P. and Rake, G., Am. Rev. Tuberc., 1949, 60, 109.

7) Rake, G., Jamber, W. P., McKee, C. M., Pancy, F., Wiselgie, F. Y. and Donovick, R., Am. Rev. Tuberc., 1949, 60, 121.

8) Arimura, K., Jicchi-ika to Rinsho, (Japanese), 1940, 17, 1150.

9) Yanagisawa, K., Nippon-rinsho (Japanese), 1948, 6, 39.

10) Ogawa, T., Nippon-rinsho-kekkaku, (Japanese), 1950, 9, 438.

11) Ogawa, T. et al.; Kekkaku (Japanese), 1949, 124, 97. 